\title{
TINJAUAN PENGETAHUAN MASYARAKAT KECAMATAN PANCA RIJANG KABUPATEN SIDRAP TERHADAP PENGGUNAAN OBAT TRADISIONAL
}

\author{
Rusli'1), Djuniasti Karim ${ }^{1)}$, Agust Dwi Djajanti ${ }^{2)}$, Chichi Ramadhani ${ }^{1)}$ \\ 1) Jurusan Farmasi Politeknik Kesehatan Kemnkes Makassar \\ 2) Akademi Farmasi Yamasi Makassar
}

\begin{abstract}
ABSTRAK
Pengobatan tradisional merupakan bentuk pelayanan pengobatan yang menggunakan cara, alat atau bahan yang tidak termasuk dalam standar pengobatan kedokteran modern dan dipergunakan sebagai alternatif pengobatan. Penggunaan tanaman obat untuk penyembuhan suatu penyakit didasarkan pada pengalaman yang secara turun - temurun yang diwariskan oleh generasi terdahulu kepada generasi berikutnya. Tanaman obat tradisional merupakan suatu komponen penting dalam pengobatan tradisional. Selain lebih ekonomis, efek samping dari obat tradisional sangat kecil. Karena itu, penggunaan obat tradisional dengan formulasi yang tepat sangat penting dan tentunya lebih aman dan efektif. Tujuan penelitian ini untuk mengetahui pengetahuan masyarakat Kecamatan Panca Rijang terhadap penggunaan obat tradisional. Penelitian ini merupakan penelitian observasional, dilakukan di Kecamatan Panca Rijang Kabupaten Sidrap pada bulan Mei - Juli 2018. Jumlah sampel yang diperoleh sebanyak 107 responden. Teknik penentuan sampel adalah simple random sampling. Hasil penelitian ini menunjukkan bahwa pengetahuan masyarakat Kecamatan Panca Rijang Kabupaten Sidrap terhadap penggunaan obat tradisional termasuk kategori tinggi $63 \%$ dan $37 \%$ responden tingkat pengetahuan masih rendah.
\end{abstract}

Kata Kunci: Tinjauan pengetahuan masyarakat, obat tradisional.

\section{Pendahuluan}

Negara Indonesia merupakan negara yang mempunyai kekayaan alam yang melimpah. Berdasarkan posisi geografisnya, wilayah negara Indonesia dilalui garis khatulistiwa yang menyebabkan wilayah Indonesia memiliki iklim tropis. Hal ini mendorong besarnya keanekaragaman hayati di Indonesia. Kekayaan alam yang ada di Indonesia sejak dahulu mendorong masyarakatnya untuk memberdayakan sumber potensi yang ada di sekitarnya, salah satu di antaranya adalah penggunaan tanaman obat dalam menyembuhkan penyakit yang lazim disebut sebagai obat tradisional (Hairunnisa, 2015).

Obat tradisional adalah bahan atau ramuan bahan yang berasal dari tumbuhtumbuhan, hewan, mineral, sediaan sarian (galenik) atau campuran dari bahan tersebut yang secara turun temurun telah digunakan untuk pengobatan (Depkes, 2000). Penggunaan tanaman obat untuk penyembuhan suatu penyakit didasarkan pada pengalaman yang secara turun - temurun yang diwariskan oleh generasi terdahulu kepada generasi berikutnya. Tanaman obat merupakan suatu komponen penting dalam pengobatan tradisional. Selain lebih ekonomis, efek samping dari obat tradisional sangat kecil. Karena itu, penggunaan obat tradisional dengan formulasi yang tepat sangat penting dan tentunya lebih aman dan efektif.Persentase penduduk Indonesia yang menggunakan obat tradisional dalam pengobatan sendiri terus meningkat selama kurun waktu tujuh tahun (2000- 2006) dari $15.2 \%$ menjadi $38.30 \%$. ( Sudibyo Supardi dan Andi Leny Susyanty, 2007).

Riset menunjukkan bahwa 49,53\% penduduk Indonesia menggunakan obat tradisional baik untuk menjaga kesehatan maupun untuk pengobatan karena sakit. Penduduk yang mengkonsumsi obat tradisional sebanyak 95,6\% menyatakan merasakan manfaat setelah mengkomsumsi obat tradisional. (Badan Litbang Kesehatan 2010). Faktor pendorong terjadinya peningkatan penggunaan obat tradisional adalah usia harapan hidup yang lebih panjang pada saat prevalensi penyakit kronik meningkat, adanya kegagalan penggunaan obat modern untuk penyakit tertentu di antaranya kanker, serta semakin luas akses informasi mengenai obat tradisional di seluruh dunia (Menyukaindar, 2006). Dari observasi pendahuluan yang dilakukan Kecamatan Panca Rijang Kabupaten Sidrap diperoleh informasi bahwa sebagian masyarakat Kecamatan Panca Rijang Kabupaten Sidrap menggunakan obat tradisonal untuk mengobati berbagai penyakit.

\section{Rumusan Masalah}

Berdasarkan latar belakang diatas, dirumuskan suatu masalah yaitu bagaimana tinjauan pengetahuan masyarakat Kecamatan Panca Rijang Kabupaten Sidrap terhadap penggunaan obat tradisional?

\section{Tujuan Penelitian}

Tujuan dari penelitian ini adalah untuk memperoleh gambaran mengenai Tinjauan 
Pengetahuan Masyarakat Kecamatan Panca Rijang Terhadap Penggunaan Obat Tradisional.

\section{Manfaat Penelitian}

Manfaat dari penenlitian ini adalah :

Untuk menghasilkan data yang berkaitan

dengan pola penggunaan obat tradisional.

\section{Jenis Penelitian}

Penelitian ini merupakan penelitian observasional yang bersifat deskriptif, yaitu berkaitan dengan pengetahuan masyarakat Kecamatan Panca Rijang Kabupaten Sidrap terhadap penggunaan obat tradisional.

\section{Tempat dan waktu penelitian}

Penelitian telah dilaksanakan di Kecamatan Panca Rijang Kabupaten Sidrap pada bulan Mei - Juli 2018.

\section{Populasi dan sampel}

Populasi

Populasi dalam penelitian ini adalah masyarakat Kecamatan Panca Rijang Kabupaten Sidrap

Sampel

Sampel dalam penelitian ini adalah masyarakat yang telah menggunakan obat tradisional dan penentuan sampel adalah random sampling. Adapun kriteria sampel dalam penelitian ini yaitu :

a. Pernah menggunakan obat tradisional

b. Berumur $\geq 18$ tahun

c. Bersedia mengisi kuesioner

Jumlah sampel dihitung berdasarkan rumus slovin

Rumus Slovin : $\mathrm{n}=\frac{\mathrm{N}}{1+\mathrm{N}(e)^{2}}$

Dimana

$\mathrm{n}=$ ukuran sampel

$\mathrm{N}=$ ukuran populasi $=25713$

$\mathrm{e}=$ tingkat kesalahan $=10 \%$

$\mathrm{n}=\frac{\mathrm{N}}{1+\mathrm{N}(e)^{2}}$

$=\frac{25713}{1+25713(10 \%)^{2}}$

$=\frac{25713}{1+25713(0.1)^{2}}$

$=\frac{25713}{1+25713(0.01)^{2}}$

$=\frac{25713}{1+257,13}$

$=\frac{25713}{258,13}$

$=106,58$ dibulatkan menjadi 107 sampel
Instrumen Penelitian yang digunakan adalah kuesioner yang dibagikan kepada responden (masyarakat) Kecamatan Panca Rijang Kabupaten Sidrap.

\section{Teknik Pengumpulan dan Pengolahan Data}

Pengumpulan data dilakukan dengan membagikan kuesioner kepada responden yang dituang dalam bentuk check list (Ya/Tidak) sehingga mempermudah pengisiannya. Data primer yang diperoleh kemudian diberi skor, dipersenkan dan penyajiannya dibuat dalam bentuk tabel.

1) Untuk jawaban $\mathrm{Ya}=1$

2) Untuk jawaban Tidak $=0$

Persentase skor =

$\frac{\text { Jumlah skor rata-rata }}{\text { skor ideal }} \times 100 \%$

Skor ideal $=$ jumlah responden $\times 1$ (jawaban tertinggi)

Jawaban yang diperoleh berdasarkan persen skor dibagi dalam 2 kategori yaitu :
a. $\leq 50 \%$
$=$ Rendah
b. $>50 \%$
= Tinggi

\section{Hasil dan Pembahasan \\ Hasil Penelitian}

Pengumpulan data penelitian dari responden yang telah dilakukan di Kecamatan Panca Rijang pada bulan Mei - Juli 2018 mengenai tinjauan pengetahuan masyarakat Kecamatan Panca Rijang Kabupaten Sidrap terhadap penggunaan obat tradisional. Penentuan sampel dilakukan dengan menggunakan metode random sampling. Sehingga diperoleh 107 responen yang telah memenuhi persyaratan berumur 18 tahun keatas, pernah menggunakan obat tradisional dan bersedia mengisi kuesioner. Data diperoleh dengan menggunakan daftar pertanyaan yang telah disusun dalam bentuk kuesioner dan dibagikan kepada responden.

Tabel 1. Karakteristik Responden Berdasarkan Jenis Kelamin

\begin{tabular}{|c|c|c|c|}
\hline No. & $\begin{array}{c}\text { Jenis } \\
\text { Kelamin }\end{array}$ & Jumlah & Persentase \\
\hline 1 & Laki-laki & 55 & $51 \%$ \\
\hline 2 & Perempuan & 52 & $49 \%$ \\
\hline \multicolumn{2}{|c|}{ Jumlah } & 107 & $100 \%$ \\
\hline
\end{tabular}

Sumber : Data Primer 2018

Berdasarkan tabel 1 dapat diketahui bahwa dari total responden terdapat $51 \%$ 
berjenis kelamin laki-laki dan $49 \%$ berjenis kelamin perempuan.

Tabel 2 Karaketeristik Responden Berdasarkan Jenis Pekerjaan

\begin{tabular}{|c|c|c|c|}
\hline No. & Pekerjaan & $\begin{array}{c}\text { Jumah } \\
\text { Responden }\end{array}$ & Persen \\
\hline 1 & Wirausaha & 40 & $37 \%$ \\
\hline 2 & Wiraswasta & 7 & $7 \%$ \\
\hline 3 & $\begin{array}{c}\text { lbu Rumah } \\
\text { Tangga }\end{array}$ & 29 & $27 \%$ \\
\hline 4 & PNS & 10 & $9 \%$ \\
\hline
\end{tabular}

\begin{tabular}{|c|c|c|c|}
\hline 5 & Mahasiswa & 20 & $19 \%$ \\
\hline 6 & Guru & 1 & $1 \%$ \\
\hline \multicolumn{2}{|c|}{ Jumlah } & 107 & $100 \%$ \\
\hline
\end{tabular}

Sumber : Data Primer 2018

Hasil penelitian yang dapat dilihat pada tabel 2 menunjukkan jenis pekerjaan masyarakat di Kecamatan Panca Rijang yaitu wirausaha sebanyak 37\%, wiraswasta sebanyak $7 \%$, ibu rumah tangga sebanyak $27 \%$, mahasiswa sebanyak $19 \%$ dan guru $1 \%$.

Tabel 3 Hasil Jawaban Responden tentang Tinjauan Pengetahuan Masyarakat Kecamatan Panca Rijang Kabupaten Sidrap terhadap Penggunaan Obat tradisional

\begin{tabular}{|r|c|c|c|c|c|c|c|c|c|}
\hline \multirow{2}{*}{ No. } & \multirow{2}{*}{$\begin{array}{c}\text { Butir } \\
\text { soal }\end{array}$} & \multicolumn{2}{|c|}{ Ya } & \multicolumn{2}{|c|}{ Tidak } & \multicolumn{2}{c|}{ Jumlah } \\
\cline { 2 - 10 } & Jawaban & Skor & Persen & Jawaban & Skor & Persen & Jawaban & Skor \\
\hline 1 & 1 & 92 & 1 & $86 \%$ & 15 & 0 & $14 \%$ & 107 & 92 \\
\hline 2 & 2 & 107 & 1 & $100 \%$ & 0 & 0 & $0 \%$ & 107 & 107 \\
\hline 3 & 3 & 81 & 1 & $76 \%$ & 26 & 0 & $24 \%$ & 107 & 81 \\
\hline 4 & 4 & 58 & 1 & $54 \%$ & 49 & 0 & $46 \%$ & 107 & 58 \\
\hline 5 & 5 & 22 & 1 & $21 \%$ & 85 & 0 & $79 \%$ & 107 & 22 \\
\hline 6 & 6 & 107 & 1 & $100 \%$ & 0 & 0 & $0 \%$ & 107 & 107 \\
\hline 7 & 7 & 101 & 1 & $94 \%$ & 6 & 0 & $6 \%$ & 107 & 101 \\
\hline 8 & 8 & 80 & 1 & $75 \%$ & 27 & 0 & $25 \%$ & 107 & 80 \\
\hline 9 & 9 & 21 & 1 & $20 \%$ & 86 & 0 & $80 \%$ & 107 & 21 \\
\hline 10 & 10 & 107 & 1 & $100 \%$ & 0 & 0 & $0 \%$ & 107 & 107 \\
\hline 11 & 11 & 91 & 1 & $85 \%$ & 16 & 0 & $15 \%$ & 107 & 91 \\
\hline 12 & 12 & 107 & 1 & $100 \%$ & 0 & 0 & $0 \%$ & 107 & 107 \\
\hline 13 & 13 & 77 & 1 & $72 \%$ & 30 & 0 & $28 \%$ & 107 & 77 \\
\hline 14 & 14 & 82 & 1 & $77 \%$ & 25 & 0 & $23 \%$ & 107 & 82 \\
\hline 15 & 15 & 87 & 1 & $81 \%$ & 20 & 0 & $19 \%$ & 107 & 87 \\
\hline 16 & 16 & 5 & 1 & $5 \%$ & 102 & 0 & $95 \%$ & 107 & 5 \\
\hline 17 & 17 & 67 & 1 & $63 \%$ & 40 & 0 & $37 \%$ & 107 & 67 \\
\hline 18 & 18 & 42 & 1 & $39 \%$ & 65 & 0 & $61 \%$ & 107 & 42 \\
\hline 19 & 19 & 6 & 1 & $6 \%$ & 101 & 0 & $94 \%$ & 107 & 6 \\
\hline 20 & 20 & 6 & 1 & $6 \%$ & 101 & 0 & $94 \%$ & 107 & 6 \\
\hline Jumlah & 1346 & 1 & $1258 \%$ & 794 & 0 & $742 \%$ & 2140 & 1346 \\
\hline Rata-rata & 67,3 & 1 & $63 \%$ & 39,7 & 0 & $37 \%$ & 107 & 67,3 \\
\hline Persentase & & $63 \%$ & & & $37 \%$ & & $100 \%$ & $63 \%$ \\
\hline Skor & & & & & & & & \\
\hline
\end{tabular}

\section{Sumber : Data Primer 2018}

Dari tabel 3 diatas dapat dilihat bahwa persentase skor jawaban Ya dari responden sebesar $63 \%$, sedangkan skor jawaban Tidak dari responden sebesar $37 \%$. 


\section{Pembahasan}

Penelitian ini telah dilakukan pada bulan Mei - Juli 2018 di Kecamatan Panca Rijang. Penarikan sampel dilakukan menggunakan metode random sampling. Sehingga diperoleh 107 responen yang telah memenuhi persyaratan, berumur 18 tahun keatas, pernah menggunakan obat tradisional dan bersedia mengisi kuesioner.

Pengumpulan data dilakukan dengan membuat angket (kuesioner) berupa data umum tentang penggunaan obat tradisional. Data yang diperoleh kemudian ditabulasi dalam bentuk tabel dan dihitung persentasenya.

Berdasarkan hasil penelitian yang telah dilakukan pada masyarakat Kecamatan Panca Rijang diperoleh data bahwa terdapat $51 \%$ responden berjenis kelamin laki-laki dan $49 \%$ berjenis kelamin perempuan.

Berdasarkan tabel jenis pekerjaan di Kecamatan Panca Rijang menunjukkan jenis pekerjaan masyarakat di Kecamatan Panca Rijang yaitu wirausaha sebanyak $37 \%$, wiraswasta sebanyak $7 \%$, ibu rumah tangga sebanyak $27 \%$, mahasiswa sebanyak $19 \%$ dan guru $1 \%$.

Pada tabel 3 terdapat 20 butir soal dimana pada butir soal nomor 1 tentang apakah anda rutin menggunakan obat tradisional untuk menjaga kesehatan. Diperoleh sebanyak $86 \%$ responden menjawab ya dan $14 \%$ menjawab tidak. Hal ini menunjukkan bahwa masyarakat di Kecamatan Panca Rijang tinggi menggunakan obat tradisional.

Pada butir soal nomor 2 menanyakan tentang apakah menurut anda obat tradisional tersebut bermanfaat untuk kesehatan. Diperoleh sebanyak $100 \%$ responden menjawab ya. Hal ini menunjukkan bahwa masyarakat di Kecamatan Panca Rijang telah mengetahui manfaat obat tradisional untuk menjaga kesehatan.

Pada butir soal nomor 3 menanyakan tentang apakah anda menggunakan obat tradisional untuk perawatan tubuh atau perawatan kecantikan. Diperoleh sebanyak $76 \%$ responden menjawab ya dan $24 \%$ menjawab tidak. Hal ini menunjukkan bahwa masyarakat di Kecamatan Panca Rijang telah menggunakan obat tradisional untuk perawatan tubuh atau perawatan kecantikan.

Pada butir soal nomor 4 menanyakan tentang apakah anda menggunakan obat tradisional untuk menangani penyakit ringan (demam, flu, batuk, pilek, sakit kepala atau diare) bagi anda atau anggota keluarga anda. Diperoleh $54 \%$ responden menjawab ya dan $46 \%$ menjawab tidak. Hal ini menunjukkan bahwa masyarakat di Kecamatan Panca Rijang menggunakan obat tradisional untuk menangani penyakit ringan.

Pada butir soal nomor 5 menanyakan jika anda atau anggota keluarga anda sakit demam, flu, batuk, pilek, sakit kepala atau diare pertolongan pertama apakah yang diberikan. Diperoleh $21 \%$ responden menjawab ya dan $79 \%$ menjawab tidak. Hal ini menunjukkan bahwa masyarakt di Kecamatan Panca Rijang tidak menggunakan obat tradisional sebagai pertolongan pertama jika mereka atau anggota keluarga mereka sakit demam, flu, batuk, pilek, sakit kepala atau diare.

Pada butir soal nomor 6 menanyakan apakah menurut anda obat tradisional lebih aman jika dibandingkan dengan obat konvensional/obat modern. Diperoleh 100\% responden menjawab ya. Hal ini menunjukkan bahwa masyarakat di Kecamatan Panca Rijang memilih obat tradisional karena lebih aman dibandingkan obat konvensional/obat modern.

Pada butir soal nomor 7 menanyakan apakah menurut anda obat tradisional memiliki khasiat yang setara dengan obat konvensional/obat modern. Diperoleh 94\% responden menjawab ya dan $6 \%$ menjawab tidak. Hal ini menunjukkan bahwa masyarakat di Kecamatan Panca Rijang menyatakan obat tradisional memiliki khasiat yang setara dengan obat konvensional/obat modern.

Pada butir soal nomor 8 menanyakan apakah menurut anda obat tradisional susah digunakan (tidak praktis/tidak nyaman dalam penggunaannya). Diperoleh $75 \%$ responden yang menjawab ya dan $25 \%$ menjawab tidak. Hal ini menunjukkan bahwa masyarakat di Kecamatan Panca Rijang menyatakan obat tradisional susah digunakan (tidak praktis/tidak nyaman dalam penggunaannya), ini merupakan salah satu alasan masyarakat kurang menggunakan obat tradisional.

Pada butir soal nomor 9 menanyakan apakah menurut anda obat tradisional mudah disiapkan / diracik). Diperoleh 20\% responden menjawab ya dan $80 \%$ menjawab tidak. Hal ini menunjukkan bahwa masyarakat di Kecamatan Panca Rijang menyatakan obat tradisional tidak mudah disiapkan / diracik), ini merupakan salah satu alasan masyarakat kurang menggunakan obat tradisional.

Pada butir soal nomor 10 menanyakan apakah menurut anda obat tradisional lebih 
ekonomis (murah) jika dibandingkan dengan konvensional/obat modern. Diperoleh 100\% responden menjawab ya. Hal ini menunjukkan bahwa masyarakat di Kecamatan Panca Rijang memilih obat tradisional dibandingkan dengan konvensional/obat modern karena lebih ekonomis.

Pada butir soal nomor 11 menanyakan apakah anda memiliki tanaman obat di pekarangan/kebun anda. Diperoleh 85\% responden menjawab ya dan $15 \%$ menjawab tidak. Hal ini menunjukkan bahwa masyarakat di Kecamatan Panca Rijang memiliki tanaman obat di pekarangan/kebun anda.

Pada butir soal nomor 12 menanyakan apakah menurut anda tanaman obat masih diperlukan di zaman modern. Diperoleh 100\% responden menjawab ya. Hal ini menunjukkan bahwa masyarakat di Kecamatan Panca Rijang masih memerlukan obat tradisional di zaman modern ini.

Pada butir soal nomor 13 menanyakan apakah tetua di keluarga anda mewariskan resep-resep obat tradisional kepada keturunannya. Diperoleh $72 \%$ responden menjawab ya dan $28 \%$ menjawab tidak. Hal ini menunjukkan bahwa masyarakat di Kecamatan Panca Rijang menyatakan tetua di keluarga mereka mewariskan resep obat tradisional kepada keturunannya.

Pada butir soal nomor 14 menanyakan apakah tetua di keluarga anda mengajarkan cara menjaga kesehatan (kebugaran) mengunakan ramuan tradisional kepada keturunannya. Diperoleh $77 \%$ responden menjawab ya dan $23 \%$ menjawab tidak. Hal ini menunjukkan bahwa masyarakat di Kecamatan Panca Rijang menyatakan tetua di keluarga mereka mengajarkan cara menjaga kesehatan (kebugaran) mengunakan ramuan tradisional kepada keturunannya.

Pada butir soal nomor 15 menanyakan apakah tetua di keluarga anda mengajarkan cara perawatan tubuh / perawatan kecantikan mengunakan ramuan tradisional kepada keturunannya. Diperoleh $81 \%$ responden menjawab ya dan $19 \%$ menjawab tidak. Hal ini menunjukkan bahwa masyarakat di Kecamatan Panca Rijang menyatakan tetua di keluarga mereka mengajarkan cara perawatan tubuh / perawatan kecantikan mengunakan ramuan tradisional kepada keturunannya.

Pada butir soal nomor 16 menanyakan apakah anda mencatat resep obat tradisional yang anda ketahui. Diperoleh $5 \%$ responden menjawab ya dan $95 \%$ menjawab tidak. Hal ini menunjukkan bahwa masyarakat di Kecamatan Panca Rijang tidak mencatat resep obat tradisional yang mereka ketahui.

Pada butir soal nomor 17 menanyakan apakah menurut anda resep-resep obat tradisional perlu dicatat/didokumentasikan. Diperoleh $63 \%$ yang menjawab ya dan $37 \%$ menjawab tidak. Hal ini menunjukkan bahwa masyarakat di Kecamatan Panca Rijang menyatakan perlu adanya dokumentasi tentang resep obat tradisional.

Pada butir soal nomor 18 menanyakan apakah anda mencatat khasiat tanamantanaman obat. Diperoleh $39 \%$ menjawab ya dan $61 \%$ menjawab tidak. Hal ini menunjukkan bahwa masyarakat di Kecamatan Panca Rijang memilih untuk tidak mencatat khasiat tanamantanaman obat karena menurut mereka semuanya telah ada di internet.

Pada butir soal nomor 19 menanyakan apakah anda mencatat cara perawatan tubuh / perawatan kecantikan mengunakan ramuan tradisional. Diperoleh 6\% menjawab ya dan 94\% menjawab tidak. Hal ini menunjukkan bahwa masyarakat di Kecamatan Panca Rijang tidak mencatat cara perawatan tubuh/perawatan kecantikan mengunakan ramuan tradisional.

Pada butir soal nomor 20 menanyakan apakah menurut anda cara perawatan tubuh / perawatan kecantikan mengunakan ramuan tradisional perlu dicatat/didokumentasikan. Diperoleh 6\% menjawab ya dan $94 \%$ menjawab tidak. Hal ini menunjukkan bahwa masyarakat di Kecamatan Panca Rijang menyatakan tidak perlu adanya pencatatan / dokumentasi cara perawatan tubuh / perawatan kecantikan mengunakan ramuan tradisional karena menurut mereka semuanya telah ada di internet.

Berdasarkan hasil pembahasan diatas dapat disimpulkan bahwa tinjauan pengetahuan masyarakat Kecamatan Panca Rijang kabupaten sidrap terhadap penggunaan obat tradisional diatas $50 \%$ yaitu $63 \%$ termasuk kategori tinggi

\section{Penutup \\ Kesimpulan}

Berdasarkan hasil penelitian dan pembahasan maka dapat disimpulkan tinjauan pengetahuan masyarakat Kecamatan Panca Rijang Kabupaten Sidrap terhadap 
penggunaan obat tradisional termasuk kategori tinggi (63\%).

Saran

Diperlukan penyuluhan tentang penggunaan obat tradisional oleh tenaga kesehatan khususnya farmasis tentang bagaimana cara pembuatan obat tradisional agar masyarakat dapat lebih mudah menggunakan obat tradisional.

\section{Daftar Pustaka}

Badan Litbang Kesehatan (2010) Laporan hasil riset kesehatan dasar tahun 2010. Jakarta: Badan Litbang Kesehatan.

Departemen Kesehatan Republik Indonesia (2006). Bahaya Bahan Kimia Obat (BKO) yang Dibubuhkan Kedalam Obat Tradisional (Jamu), Badan Pengawasan Obat dan Makanan, Jakarta.

Departemen Kesehatan Republik Indonesia., 2000, Pedoman Pelaksanaan Uji Klinik Obat Tradisional, Pengawasan Obat dan Makanan Direktorat Pengawasan Obat Tradisional, Jakarta.

Departemen kesehatan RI. (1994). Keputusan Menteri kesehatan Republik Indonesia Nomor 661/MENKES/SK/SK/VII/1994 tentang persyaratan Obat Tradisional. Jakarta: Departemen kesehatan RI.

Departemen kesehatan RI. (1995). Materia Medika Indonesia, Jilid VI. Jakarta: Direktorat Jenderal Pengawasan Obat dan Makanan.
Hairunnisa. 2015. Tanaman Obat Pilihan Masyarakat Di Dusun Likuloe Desa Bontoramba Kecamatan Pallangga Kabupaten Gowa Yang DigunakanSebagai Obat Diare. Poltekkes Makassar. Makassar.

Hutapea, J.R, 2000, Inventaris Tanaman Obat Indonesia (I) Jilid 1, Departemen Kesehatan Republik Indonesia, Jakarta.

Harmanto, Ning, Subroto, M. Ahkam, 2007, Pilih Kamu dan Herbal Tanpa Efek Samping, PT Elex Media Komputindo, Jakarta.

Menyukaindar EY. 2006. Trend an Paradigma Dunia Farmasi, Industri-Klinik-Teknologi Kesehatan, disampaikan dalam orasi ilmiah Dies Natalis ITB, (diunduh Maret 2018)

Peraturan Menteri Kesehatan No. 007 Tahun 2012 Tentang Registrasi Obat Tradisional. Peraturan Kepala Badan POM RI No. HK.00.05.4.2411 tahun 2004 tentang Ketentuan Pokok Pengelompokan \& Penandaan Obat Bahan Alam Indonesia.

Supardi, Sudibyo dan Andi Leny Susyanty, 2007, Penggunaan Obat Tradisional Dalam Upaya Pengobatan Sendiri Di Indonesia (Analisis Data Susenas Tahun 2007), Pusat Penelitian dan Pengembangan Sistem dan Kebijakan Kesehatan, Jakarta.

Tilaar, M., 1998, Pandangan Industri Obat Tradisional Terhadap Penyediaan Simplisia Tanaman Obat dari Hasil Budidaya, Jakarta: Direktorat Pengawasan Obat dan Makanan. 